\title{
Potensi Ekstrak Makroalga Watercress sebagai Anti Bakteri Aeromonas hydrophila secara in vitro
}

\author{
Potency of Watercress Extract as Anti-Bacterial against Aeromonas hydrophila in \\ vitro
}

\author{
Qurrota A'yunin $^{1 *}$, Dinarti' ${ }^{2}$, Nurhabibah ${ }^{1}$, Budianto $^{1}$ \\ ${ }^{1}$ Program Studi Budidaya Perairan, Fakultas Perikanan dan Ilmu Kelautan, Universitas \\ Brawijaya, Malang. \\ ${ }^{2}$ Laboratorium Mikrobiologi, Balai Pengujian Kesehatan Ikan dan Lingkungan, Serang. \\ *Korespondensi: qurrota_ayunin@ub.ac.id
}

\begin{abstract}
ABSTRAK
Infeksi penyakit menjadi satu masalah yang masih sering timbul pada budidaya ikan patin. Salah satu penyakit yang sering timbul dalam budidaya ikan patin adalah penyakit Motile Aeromonas Septicemia (MAS) yang dapat menginfeksi kelompok Catfish dengan tingkat kematian yang tinggi. Ekstrak makroalga watercress diduga dapat menghambat pertumbuhan bakteri patogen yang menginfeksi ikan patin. Bakteri yang menginfeksi ikan patin dikultur dan didentifaksi secara biokimia. Pengujian ekstrak dilakukan melalui uji daya hambat dengan dosis yang berbeda untuk mengetahui aktifitas ekstrak dalam menghambat pertumbuhan bakteri. Berdasarkan hasil identifikasi biokimia, didapatkan bakteri patogen yang menginfeksi ikan patin yaitu Aeromonas hydrophila. Hasil uji daya hambat menunjukkan dosis $70 \mathrm{ppm}$ memiliki respon hambatan tertinggi dibandingkan dengan dosis lainnya. Hal ini menunjukkan bahwa ekstrak makroalga watercress dapat menghambat pertumbuhan bakteri patogen sehingga natinya dapat digunakan sebagai alternatif obat dalam mengatasi infeksi bakteri Aeromonas hydrophila pada ikan.
\end{abstract}

Kata kunci: daya hambat; ekstrak watercress; makroalga; mikroba

\begin{abstract}
Disease infection is a problem in catfish farming. The diseases that often arise in catfish farming is Motile Aeromonas Septicemia (MAS). It can infect the catfish group with a high mortality rate. Watercress extract is thought to inhibit the growth of pathogenic bacteria that infect catfish. Bacteria that infect catfish are cultured and biochemically identified. The extracts test was carried out through an inhibition tests with different doses to determine the activity of extracts in inhibiting bacterial growth. Based on the results of biochemical identification, the pathogenic bacteria that infect catfish are Aeromonas hydrophila. The results of the inhibition test showed that a dose of $70 \mathrm{ppm}$ had the highest inhibitory response compared to other doses. This indicates that watercress macroalgae extract can inhibit the growth of pathogenic bacteria so it can be used as an alternative medicine to treat Aeromonas hydrophila infection in fish.
\end{abstract}

Keywords: inhibition; watercress extract; macroalgae; microbes 


\section{PENDAHULUAN}

Masih rendahnya produksi ikan patin oleh pembudidaya lokal salah satunya disebabkan oleh tingginya angka kematian ikan pada saat proses budidaya. Hal tersebut juga dialami oleh pembudidaya ikan patin yang ada di Sidoarjo yang mengalami gagal panen akibat adanya kematian masal pada ikan patin yang dibudayakan. Berdasarkan laporan penelitian sebelumnya A'yunin et al., (2019) menunjukkan bahwa agen penyebab kematian pada ikan patin di Sidoarjo adalah adanya infeksi bakteri Aeromonas hydrophila.

Infeksi penyakit merupakan salah satu ancaman di bidang ketahanan pangan dalam budidaya perikanan. Aeromonas hydrophila merupakan bakteri yang menyebabkan wabah penyakit Motile Aeromonas Septicemia (MAS) yang dapat menginfeksi kelompok Catfish (Baumgartner et al., 2017) dengan tingkat kematian yang tinggi mencapai $100 \%$ hanya dalam waktu singkat (614 hari).

Tanaman termasuk juga makrolaga dikenal memiliki kemampuan menghasilkan metabolit sekunder yang tinggi dan memiliki kemampuan mengobati penyakit. Menurut Klimek-Szczykutowicz , et al., (2020) bahwa watercress termasuk tanaman air yang mengandung senyawa isothiocyanates yang berperan sebagai anti-oksidan, anti-kanker, anti-bakteri dan anti-inflamatory.

Metode penanggulangan penyakit pada ikan air tawar yang sering digunakan oleh pembudidaya adalah dengan menggunakan zat ki-mia atau antibiotika. Pada umumnya pembudidaya sering melakukan pemberian berbagai macam antibiotik seperti ampicillin, chloramphenicol, tetracycline dan disinfektan pada ikan yang terserang penyakit (A'yu-nin et al., 2019). Akan tetapi, peng-gunaan antibiotik dapat menimbul-kan dampak negatif bagi lingku-ngan dan konsumen, diantaranya yaitu timbulnya resistensi bakteri patogen dan adanya residu antibiotik. Penggunaan antibiotik secara terus menerus tentunya dapat membahasayakan lingkungan dan juga kesehatan baik ikan maupun manusia yang mengkonsumsinya sehingga perlu adanya obat alternative pengganti antibiotik yang memiliki dampak positif dan ramah lingkungan.

\section{METODE PENELITIAN}

\section{Ekstraksi Makroalga Watercress}

Ekstraksi sampel dilakukan dengan metode maserasi (perendaman). Watercress yang telah dikeringkan dan berbentuk serbuk ditimbang sebanyak 150 gram. Satu bagian serbuk watercress dimasukkan ke dalam maserator, ditambahkan 2 bagian pelarut metanol. Maserasi dilakukan selama 24 jam, kemudian ektrak disaring dan ganti dengan pelarut yang baru dan diulang sebanyak 3 kali (Khoiriyah et al., 2014). Ektsrak yang diperoleh diuapkan dengan menggunakan rotary evaporator hingga diperoleh pasta dan selanjutnya difraksinasi dengan menggunakan corong pisah dengan pelarut Etil asetat dan air (Putri et al., 2016). Hasil fraksinasi berupa fraksi etil asetat dan fraksi air diuapkan kembali hingga diperoleh pasta dan disimpan dalam kulkas hingga digunakan dalam uji selanjutnya.

\section{Identifikasi Bakteri}

Proses kegiatan identifikasi bakteri pada penelitian ini dilakukan dengan uji morfologi dan uji biokimia untuk mengetahui bentuk bentuk morfologi dan karakteristik dari sifat 
biokimia yang dimilikinya. Bakteri diinokulasi dari organ target pada ikan yang sakit yaitu pada organ ginjal. Ikan yang sakit diambil dari pembudidaya ikan yang berada di daerah Sidoarjo, Jawa Timur.

\section{Kultur Bakteri}

TSB ditimbang sebanyak 30 gram kemudian dilarutkan dalam $1000 \mathrm{ml}$ aquades di dalam erlemeyer. Kemudian erlenmeyer ditutup dengan kapas dan aluminium foil. Media TSB dididihkan di atas hotplate sambil hingga media media larut. Setelah itu media disterilkan dalam autoclave pada suhu $121^{\circ} \mathrm{C}$, tekanan 1 atm selama 15 menit (Huyyirnah dan Fitriyani, 2020).

Regenerasi bakteri uji dilakukan dengan menginokulasikan satu ose stok bakteri ke dalam media agar. Inkubasi dilakukan pada suhu $25^{\circ} \mathrm{C}$ selama 24 jam. Selanjutnya bakteri diinokulasikan ke dalam media cair dan di inkubasikan selama pada suhu $25^{\circ} \mathrm{C}$ hingga mencapai ke-padatan $10^{6}$ atau setara dengan stan-dar Mc Farland (Sinurat et al., 2019).

\section{Uji Daya Hambat}

Sebanyak $100 \mu \mathrm{L}$ bakteri ini di inokulasikan pada media agar dan dinkubasi selama 30 menit, kemudian cakram uji diletakkan di permukaan agar. Uji in vitro dilakukan dengan mengacu Volk and Wheeler (1988) yaitu merendam kertas cakram dalam larutan ekstrak watercress selama 15 menit, kemudian diletakkan di atas permukaan media bakteri dengan pinset dan ditekan sedikit kemudian diinkubasikan selama 24 jam pada suhu $25^{\circ} \mathrm{C}$ dalam inkubator. Pembacaan zona hambat dilakukan setelah 24 jam dari waktu inkubasi, diameter zona hambatan yang terbentuk kemudian diukur dengan jangka sorong.

Uji diameter zona hambatan terhadap antibiotik juga dilakukan untuk membandingkan antara uji efektivitas senyawa bioaktif watercress dengan antibiotik. Uji diameter zona hambatan yakni dengan menggunakan antiobiotik Oxytetracycline 1-8 $\mu \mathrm{g} / \mathrm{ml}$ (Juntarut et al., 2018). Cakram antiobiotik diletakkan di atas permukaan media bakteri dengan pinset dan ditekan sedikit kemudian diinkubasikan selama 24 jam pada suhu $25^{\circ} \mathrm{C}$ dalam inkubator. Pembacaan zona hambat dilakukan setelah 24 jam dari waktu inkubasi, diameter zona hambatan yang terbentuk kemudian diukur dengan jangka sorong.

\section{HASIL DAN PEMBAHASAN}

\section{Ekstrak Makroalga Watercress}

Ekstrak yang dihasilkan dari proses maserasi ini sebanyak 28,63 gram dengan rendemen ekstrak sebesar $14,32 \%$. Rendemen dipengaruhi oleh kadar air yang terkandung dalam simplisia. Semakin rendah kadar air, maka rendemen yang dihasilkan semakin besar nilainya (Rahman et al., 2017). Ekstrak methanol yang dihasilkan kemudian difraksinasi dengan metode partisi cair - cair. Metode ini merupakan metode pemisahan senyawa kimia berdasarkan tingkat kepolaran senyawa yang terkandung dalam ekstrak dengan perbandigan konsentrasi yang tetap (Gu, 2000).

\section{Identifikasi Bakteri}

Hasil pewarnaan berwarna merah maka menunjukkan bahwa bakteri tersebut adalah gram negative (Fajriani et al., 2018). Selain itu hasil uji gram menggunakan $\mathrm{KOH} 3 \%$ juga 
menunjukkan hasil negative yang ditandai dengan terbentuknya lendir pada object glass yang di-campur dengan bakteri. Menurut Waluyo (2005), adanya lendir dise-babkan karena komponen peptidog-likan yang tipis pada sel gram negatif sehingga menyebabkan sel mudah pecah. Tahapan identifikasi selanjutnya yaitu melalui uji biokimia. Hasil identifikasi terlihat pada tabel 1 .

Tabel 1. Identifikasi Bakteri

\begin{tabular}{lcc}
\hline Parameter & Kontrol & Sampel \\
\hline Gram: & - & - \\
$\quad$ Pewarnaan & - & - \\
$\quad$ KOH 3\% & & + \\
Katalase & + & + \\
Oksidase & + & + \\
Motilitas & + & + \\
Indol & + & + \\
Ornithine & - & - \\
Citrate & + & + \\
O/F & $\mathrm{F}$ & $\mathrm{F}$ \\
Urea & - & - \\
MR & + & + \\
VP & + & + \\
Lysine & & \\
Decarboxylas & + & + \\
e & & \\
Glukosa & + & + \\
Maltose & + & + \\
Laktosa & + & + \\
Sukrosa & + & + \\
$\quad$ Hasil & Aeromona & Aeromona \\
Identifikasi & s & s \\
& hydrophil & hydrophil \\
& $a$ & $a$ \\
\hline
\end{tabular}

Pada uji oksidase, bakteri positif oksidasi menunjukkan perubahan menjadi warna hitam pada waktu 2 menit karena adanya reaksi sitokrom oksidase yang terdapat pada bakteri A. Hydrophila (Mus-takim et al., 2014). Sedangkan pada uji indol menunjukkan adanya perubahan warna menjadi merah seperti membentuk cincin pada permukaan agar miring yang telah diinokulasi bakteri didalamnya keti-ka diberikan pereaksi indol yang menandakan reaksi indol positif (Sari et al., 2019).

Uji Katalase dilakukan guna mengetahui adanya katalase yang ada pada bakteri. Katalase meru-pakan enzim yang digunakan oleh mikroba untuk menguraikan $\mathrm{H}_{2} \mathrm{O}_{2}$ menjadi $\mathrm{H}_{2} \mathrm{O}$ dan $\mathrm{O}_{2}$. Hasil positif terlihat adanya pembentukan gelem-bung gas di atas koloni sedangkan negatif berarti tidak terjadi pem-bentukan gelembung pada sekitar area koloni. Menurut Mustakim et al., (2014), hal tersebut disebabkan karena larutan yang diberikan dapat membentuk adanya gelembung di sekitar pertumbuhan koloni bakteri, dan Lubis et al., (2014) menyatakan bahwa hydrogen peroksida bersifat toksik terhadap sel karena menginaktifasikan enzim dalam sel.

Uji VP dilakukan dengan menginokulasikan bakteri pada media MRVP, lalu diinkubasi dan ditambahkan dengan larutan naftol dan $\mathrm{KOH} 40 \%$ dan didiamkan bebe-rapa menit. Menurut Sari et al., (2019), indikator positif yaitu dengan adanya perubahan warna merah mu-da sampai tua dan indikator negatif VP adalah tidak terjadinya peruba-han warna yang berarti pada media.

\section{Daya Hambat Ektstrak Watercress}

Perlakuan dosis pada uji cakram di penelitian ini menggunakan dosis 10, 20, 30, 40, 50, 60, 70, 80, 90, 100 ppm, kontrol positif dan kontrol negative. Hasil gambar uji daya hambat ekstrak terhadap bakteri A. hydrophila setelah pembe-rian ekstrak watercress disajikan pada Gambar 1. 


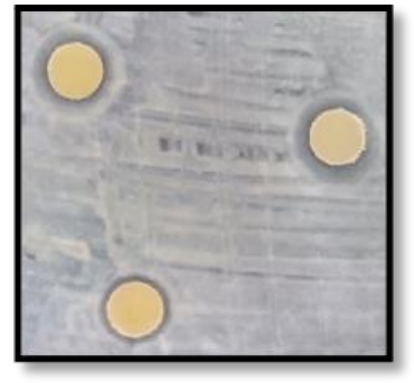

Gambar 1. Uji daya hambat ekstrak watercress $(9 \mathrm{~mm})$ dengan pelarut methanol.

Hasil pengamatan yang dilakukan selama inkubasi 24 jam dalam inkubator dengan suhu $32^{\circ} \mathrm{C}$ dilakukan pengukuran menggunakan jangka sorong $(\mathrm{mm})$, selanjutnya didapatkan hasil rata-rata diameter zona bening perlakuan ekstrak $w a$ tercress dengan hasil disajikan pada gambar 2.

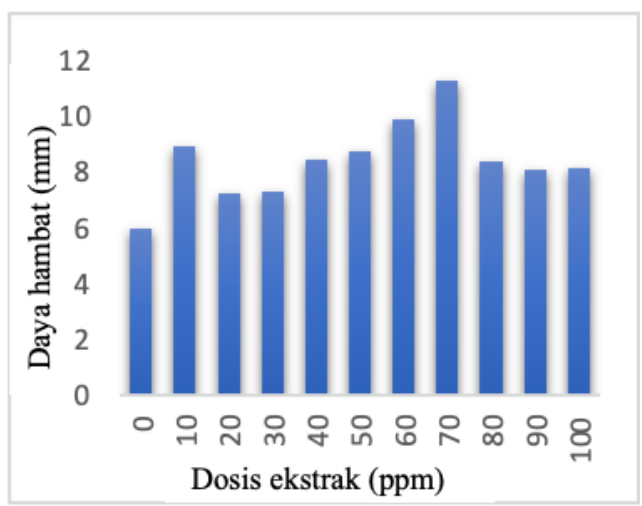

Gambar 2. Hasil daya hambat ekstrak watercress dengan dosis yang berbeda

Berdasarkan hasil uji daya hambat pada dosis $70 \mathrm{ppm}$ terlihat daya hambat yang paling tinggi diantara dosis perlakukan yang lain. Ekstrak makroalga watercress memiliki senyawa aktif alkaloid yang dapat menghambat pertumbuhan bakteri melalui mekanisme kerja dengan cara berinteraksi dengan dinding sel yang menyebabkan kerusakan dinding sel. Alkaloid juga dapat berikatan dengan DNA bakteri yang me- nyebabkan kegagalan sintesis protein (Putri et al., 2016). Dikutip dari Barodah et al., (2016), kandungan aktif saponin merupakan senyawa yang dapat membentuk busa dan merusak membran sel karena bisa membentuk ikatan dengan lipida dari membran sel. Saponin bekerja sebagai antibakteri dengan mengganggu stabilitas membran sel bakteri sehingga menyebabkan sel bakteri lisis atau senyawa saponin akan merusak membran sitoplasma dan membunuh sel membran sitoplasma. Pada golongan kandungan aktif fenol memiliki mekanisme kerja dengan cara menembus dan merusak dinding sel kemudian mengendapkan protein sehingga menjadi racun dalam protoplasma sel bakteri. Fenol dapat menyebabkan cairan sel bakteri keluar (lisis), maka senyawa bahan aktif masuk ke dalam sel bakteri, mengakibatkan terjadi kebocoran metabolit esensial yang dibentuk oleh bakteri serta merusak permeabilitas membran sel (Nopandi et al., 2019).

\section{KESIMPULAN}

Bakteri patogen yang menginfeksi ikan patin yaitu Aeromonas hydrophila. Ekstrak makroalga watercress dapat menghambat pertumbuhan bakteri Aeromonas hydrophila dan ekstrak dengan dosis 70 ppm menunjukkan daya hambat tertinggi jika dibandingkan dosis lainnya. Hal ini menunjukkan potensi watercress secara in vitro yang dapat menghambat pertumbuhan bakteri patogen dan dapat digunakan sebagai alternatif obat dalam mengatasi infeksi bakte-ri pada ikan.

\section{UCAPAN TERIMAKASIH}

Terimakasih kepada Universitas Brawijaya yang telah memberi- 
kan Hibah Penelitian dengan skema Hibah Peneliti Pemula (HPP) tahun 2021.

\section{DAFTAR PUSTAKA}

A'yunin, Q., Kartikaningsih, H., Andayani, S., Surantika, M., Fani, F., Soeprijanto, A., \& Nasrullah, B. A. (2019). Efikasi Oxytetracycline terhadap Kesehatan Ikan Lele (Clarias sp.) yang Diinfeksi Bakteri Edwardsiella tarda. Journal of Fisheries and Marine Research, 3(1), 105110.

Barodah, L. L., Sumardianto, S., \& Susanto. (2016). Efektivitas Serbuk Sargassum Polycystum Sebagai Antibakteri Pada Ikan Lele (Clarias Sp.) Selama Penyimpanan Dingin. Jurnal Pengolahan dan Bioteknologi Hasil Perikanan, 6, 10-20.

Baumgartner, W. A., Ford, L., \& Hanson, L. (2017). Lessions Caused by Virulent Aeromonas hydrophila in Farmed Catfish (Ictalurus punctatus and I. punctatus x I. furcatus) in Mississippi. Journal of Veterinary Diagnostic Investigation, 29(5), 747-751.

Fajriani, B., Budiharjo, A., Pujiyanto, S. (2018). Isolasi dan Identifikasi Molekular Bakteri Antagonis terhadap Vibrio parahaemolyticus Patogen pada Udang Litopenaeus Vannamei dari Produk Probiotik dan Sedimen Mangrov di Rembang. Jurnal Biologi, 7(1), 52-63.

Gu, T. (2000). Liquid-Liquid Partitioning Methods for Biose- parations, Academic Press, 2,329-364.

Juntarut, P., S. Kaewnopparat, D. Faroongsarng, \& S. Chiayvareesajja. (2018). The in vitro efficacy of oxytetracycline against reisolated pathogenic Aeromonas hydrophila carrying the cytolytic enterotoxin gene through hybrid catfish, Clarias macrocephalus (Günther, 1864) $\times$ Clarias gariepinus (Burchell, 1822) in Thailand. Aquaculture Research, 49(5). 1848-1857.

Khoiriyah, S., Hanapi, A., \& Fasya, A. G. (2014). Uji fitokimia dan aktivitas antibakteri fraksi etil asetat, kloroform dan petroleum eter ekstrak metanol alga coklat sargassum vulgare dari pantai kapong pamekasan madura. Alchemy, 3(1). $\quad$ https://doi.org/ 10.18860/al.v0i1.2914.

Klimek-Szczykutowicz, M., Dziurka, M., Blazevic, I., Dulovic, A., Granica, S., Korona-Glowniak, I., Ekiert, H., dan Szopa, A. (2020). Phytoche-mical And Biochemical Acti-vity Studies on Nasturtium Officinale (Waterceress) Microshoot Culture Grown in RITA® Temporary Immersion Systems. Molecules, 25, 5257.

Nopandi, H., Pratama, R. I., Suryana, A. A. H., \& Rostini, I. (2019). Penambahan Ekstrak Kunyit Terhadap Karakteris-tik Presto Ikan Nila yang Disimpan Pada Suhu Kamar. Jurnal Perikanan Kelautan, 2 , 50-55. 
Putri, R. R., Hasanah, R., \& Kusimaningrum, I. (2016). Uji aktivitas antibakteri dan Uji fitokimia ekstrak daun mangrove Sonneratia alba. Aquawarman Jurnal Sains Dan Teknologi Akuakultur, 2, 43-50.

Rahman, D. R., Rimbawan, Madanijah, S., dan Purwaningsih, S. (2017). Potensi Selada Air (Nasturtium Officinale R.Br) Sebagai Antioksidan dan Agen Antipoliferasi terhadap Sel MCF-7 Secara In
Vitro. Jurnal Gizi Pangan, 12(3), 217-224.

Sinurat, A. A. P., Renta, P. P., Herliany, N. E., Negara, B. F., \& Purnama, D. (2019). Uji Aktivitas Antibakteri Ekstrak Metanol Rumput Laut Gracilaria edulis terhadap Bakteri Aeromonas hydrophila. Jurnal Enggano, 4(1), 105-114.

Volk, W. A. \& M. F. Wheeler. (1988). Mikrobiologi Dasar. Edisi 5. Alih Bahasa. Mark-ham. Erlangga. Jakarta. $712 \mathrm{hlm}$. 
